\title{
Sistem Komunikasi Suara Bawah Air dengan Metoda Simplex menggunakan Visible Light Communication (VLC)
}

\section{LUCIA JAMBOLA, ARSYAD RAMADHAN DARLIS, LITA LIDYAWATI, DZIKRI FACHRI HUSAENI}

\author{
Teknik Elektro Institut Teknologi Nasional Bandung \\ Email : shafihazidrahman@gmail.com \\ Received 25 Maret 2019 | Revised 8 April 2019 | Accepted 18 Mei 2019
}

\begin{abstract}
ABSTRAK
Sistem komunikasi suara bawah air telah dikenal sejak lama, diantaranya sonar dan akustik. Seiring perkembangan zaman dan kemajuan teknologi, kini hadir komunikasi dengan media transmisi cahaya tampak yaitu Visible Light Communication (VLC) yang dapat diterapkan pada komunikasi bawah air. Pada penelitian ini telah dilakukan komunikasi suara bawah air (simplex) menggunakan $V L C$, dengan media akuarium berisi air dan beberapa pengujian diantaranya menggunakan color filter, didapat hasil pengujian terbaik yaitu tegangan 4,4 Vp$p$ dan frekuensi 3,003 kHz untuk color filter yellow, pengujian menggunakan lensa didapat hasil pengujian terbaik yaitu tegangan 4,4 Vp-p dan frekuensi 3,051 kHz untuk lensa (+50), dan pengujian terakhir menggunakan lampu UV didapat hasil pengujian terbaik dengan tegangan 4,4 Vp-p dan frekuensi 3,010 kHz. Implementasi sistem VLC ini menunjukkan hasil yang baik dan layak untuk diterapkan pada komunikasi suara bawah air (simplex).
\end{abstract}

Kata kunci: VLC, Komunikasi Suara Bawah Air, Simplex.

\section{ABSTRACT}

Underwater voice communication systems have been known for a long time, including sonar and acoustics. Along with the development and advancement of technology, now there is communication with visible light transmission media, namely Visible Light Communication (VLC) which can be applied to underwater communication. Under this study underwater voice communication (simplex) has been carried out using VLC, with aquarium media containing water and several tests including using a color filter, the best test results obtained are voltage 4.4 $V p-p$ and frequency $3.003 \mathrm{kHz}$ for yellow color filter, testing using the lens obtained the best test results namely voltage $4.4 \mathrm{Vp}$ - $p$ and frequency $3.051 \mathrm{kHz}$ for lenses $(+50)$, and the last test using UV lights obtained the best test results with a voltage of $4.4 \mathrm{Vp}-\mathrm{p}$ and a frequency of $3.010 \mathrm{kHz}$. The implementation of the VLC system shows good and feasible results to be applied to underwater voice communication (simplex).

Keywords: VLC, Underwater Voice Communication, Simplex. 


\section{PENDAhULUAN}

Indonesia merupakan negara yang sebagian besar wilayahnya berupa lautan. Hal ini memungkinkan adanya perkembangan teknologi di bidang pelayaran, perikanan, militer dan hal-hal lain yang berhubungan dengan potensi Indonesia di bidang maritim. Salah satu pengembangan teknologi untuk dapat mengoptimalkan potensi Indonesia di bidang maritim adalah sistem komunikasi bawah air.

Sistem komunikasi suara bawah air telah dikenal sejak lama, diantaranya sonar dan akustik. Seiring perkembangan zaman dan kemajuan teknologi, kini hadir komunikasi dengan media transmisi cahaya tampak yaitu Visible Light communication (VLC) yang dapat diterapkan pada komunikasi bawah air. Sistem VLC memiliki kelebihan yaitu bit rate yang lebih tinggi dibandingkan sistem komunikasi bawah air yang sudah ada (Deztrez dkk, 2012).

Pada saat ini cahaya tampak (visible light) tidak lagi digunakan hanya sebagai media penerangan, tetapi sudah dapat digunakan sebagai media penyampaian informasi. Dengan adanya teknologi yang memanfaatkan cahaya tampak sebagai media komunikasi, seseorang tidak harus membeli sebuah access point untuk menerima data, tetapi cukup dengan menggunakan cahaya tampak dari lampu saja. Dengan demikian tingkat efisiensi dan mobilitas akan lebih tinggi. Hanya dengan menghidupkan lampu saja maka komunikasi data dapat dilakukan. Dengan teknologi seperti ini, seseorang dapat menciptakan sebuah komunikasi dengan cara mengirimkan file audio (misal musik, rekaman) dan video dari satu tempat ke tempat lain dalam sebuah ruangan, mencetak dokumen dengan jarak yang jauh tanpa menggunakan kabel, dan aplikasi lainnya.

Bermula dari penelitian yang dilakukan oleh (Alain Destrez, dkk, 2012), dimana untuk komunikasi bawah air menggunakan sistem komunikasi optik akan memiliki nilai bit rate yang tinggi dibandingkan sistem komunikasi bawah air lainnya. Penelitian selanjutnya dilakukan oleh (Darlis, dkk, 2016), dimana sistem VLC telah berhasil diimplementasikan dengan baik pada jarak pengiriman sinyal audio sebesar 2,5 m dengan range frekuensi $600 \mathrm{~Hz}$ sampai dengan $45 \mathrm{kHz}$.

Berbeda dengan penelitian yang dilakukan oleh (G. Cossu, dkk, 2012), sistem komunikasi cahaya tampak secara eksperimental ditunjukkan dengan menggunakan RGB LED yang dimodulasi dengan sinyal DMT. Penelitian ini mencapai kecepatan data sampai $780 \mathrm{Mbit} / \mathrm{s}$ dengan jarak 2,5 m antara langit ke lantai. Terdapat penelitian yang telah dikerjakan oleh (Arsyad dkk, 2018) yang menggunakan media air tawar dengan metode bidirectional. Pada penelitian ini dibuat suatu sistem komunikasi bawah air menggunakan VLC dengan media air laut satu arah dan untuk membandingkan kinerja sistem komunikasi bawah air menggunakan VLC ini dibuat beberapa kondisi yaitu tanpa adanya color filter dan lensa (tanpa skenario), menggunakan color filter, menggunakan lensa dan dalam kondisi gelap.

\section{METODOLOGI PENELITIAN}

\subsection{Perancangan Sistem}

Perancangan sistem ini meliputi blok pengirim (Tx) dan blok penerima (Rx) yang diletakkan di dalam akuarium berisi air. Blok diagram sistem seperti pada Gambar 1. 


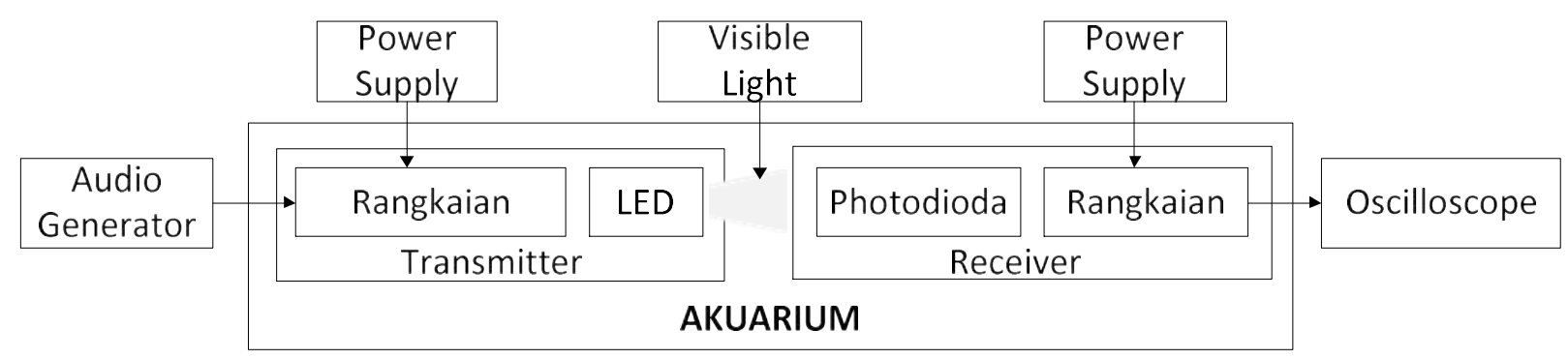

Gambar 1. Blok Diagram Sistem Visible Light Communication pada Akuarium

Fungsi dari masing-masing blok akan dijelaskan sebagai berikut :

1. Lampu LED berfungsi sebagai sumber cahaya dan sebagai pengirim.

2. Photodioda berfungsi untuk pengubah sinyal cahaya menjadi sinyal listrik dan sebagai penerima data pada blok ini.

3. Pada bagian input digunakan audio generator sebagai sinyal informasi dengan frekuensi $3000 \mathrm{~Hz}$.

4. Pada bagian output digunakan oscilloscope.

\subsection{Implementasi Sistem Transmitter(Tx)}

Pada bagian transmitter ini terjadi proses perubahan sinyal informasi atau data yang berasal dari audio generator menjadi cahaya, yang akan ditransmisikan melalui LED. Pada saat mengirimkan data berupa gelombang cahaya tampak, LED akan memancarkan gelombang cahaya tampak sesuai data pengirimnya. Pada rangkaian Tx ini terdiri dari beberapa komponen dan alat pendukung, yaitu audio generator, LED, Tx dengan rangkaian RC sederhana.

Spesifikasi sistem transmitter adalah sebagai berikut :

1. Respon Frekuensi $\quad: 2700-3400 \mathrm{~Hz}$

2. Sumber Daya : Power Supply (9V)

3. LED : 3 LED (5 watt)

4. Resistor : 100 dan 75 ohm

5. Kapasitor : $330 \mathrm{nF}$ dan $330 \mathrm{pF}$

Gambar rangkaian transmitter dan hasil implementasi sistem transmitter dapat dilihat pada Gambar 2 dan Gambar 3.

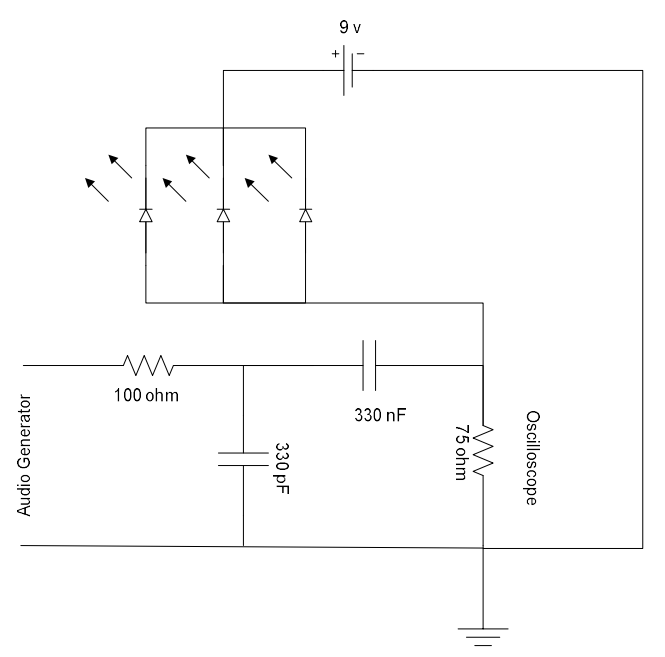

Gambar 2. Rangkaian Transmitter. 

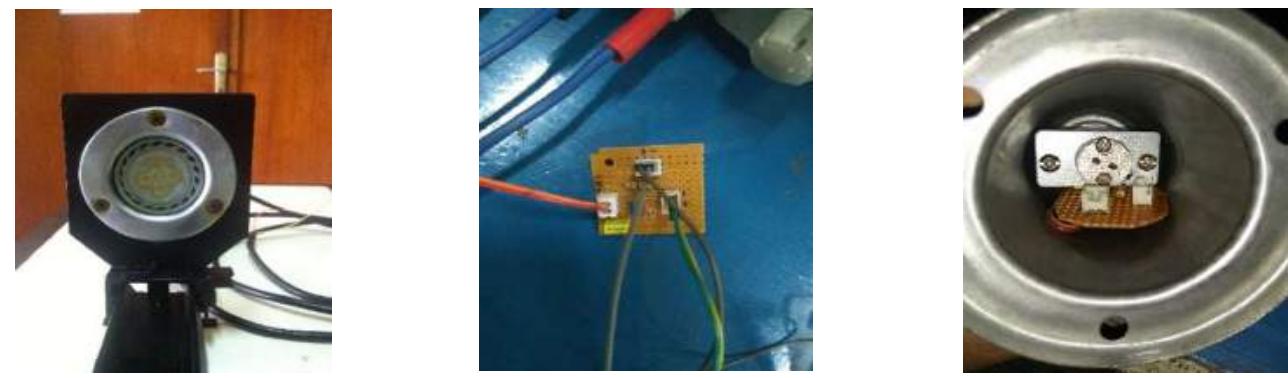

Gambar 3. Hasil Implementasi Sistem Transmitter.

\subsection{Implementasi Sistem Receiver(Rx)}

Pada bagian receiver menggunakan photodioda, yang berfungsi sebagai sensor cahaya. Cara kerja dari sistem Rx ini adalah sinyal informasi yang dikirimkan oleh LED akan diterima oleh photodioda, dan kemudian diterima oleh Transistor BC547 yang berfungsi sebagai amplifier audio.

Spesifikasi sistem receiver dari rangkaian pada Gambar 2 di atas adalah sebagai berikut:
1. Sumber Daya : Power Supply (9V)
2. Photodioda : $3 \mathrm{~mm}$
3. Transistor : BC547
4. Resistor : 100 ohm, $1 \mathrm{~K}$ ohm, $1 \mathrm{M}$ ohm, 470K ohm, 56K ohm,
5. Kapasitor $\quad \begin{array}{ll}3,3 \mathrm{~K} \text { ohm } \\ : 100 \mathrm{nF} 2 \text { pcs }\end{array}$

Gambar rangkaian receiver dan rangkaian implementasi rangkaian receiver dapat dilihat pada Gambar 4 dan Gambar 5.

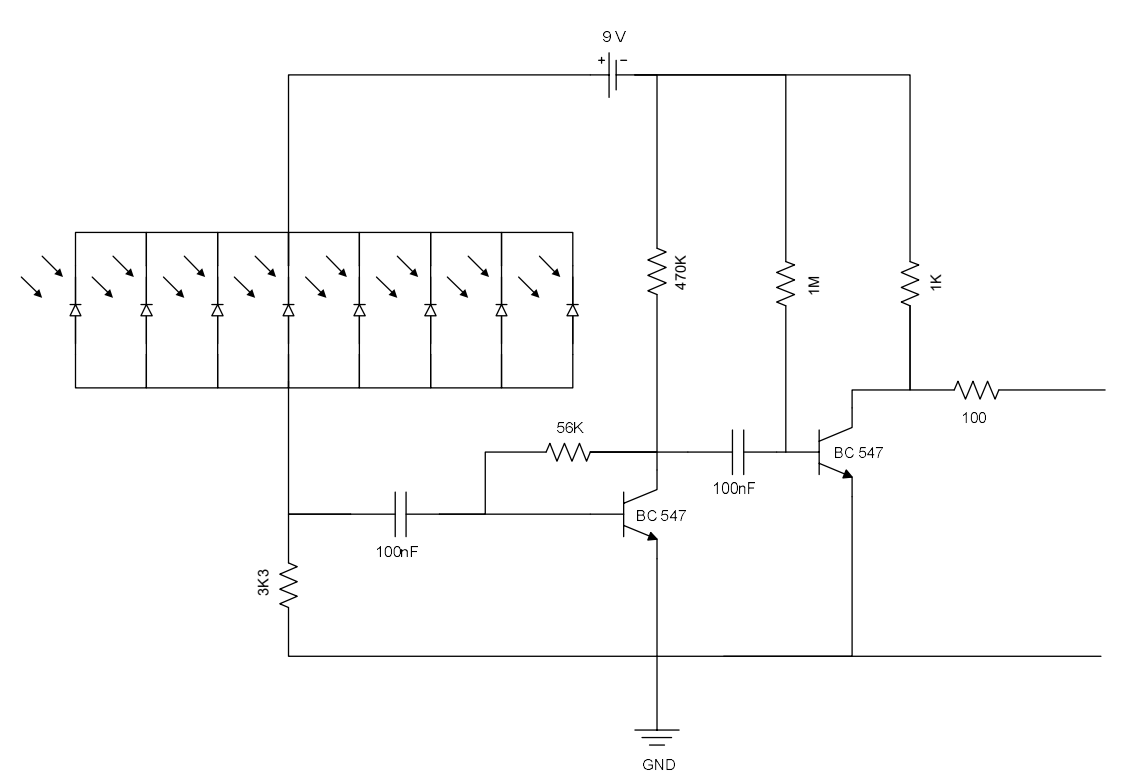

Gambar 4. Rangkaian Receiver 

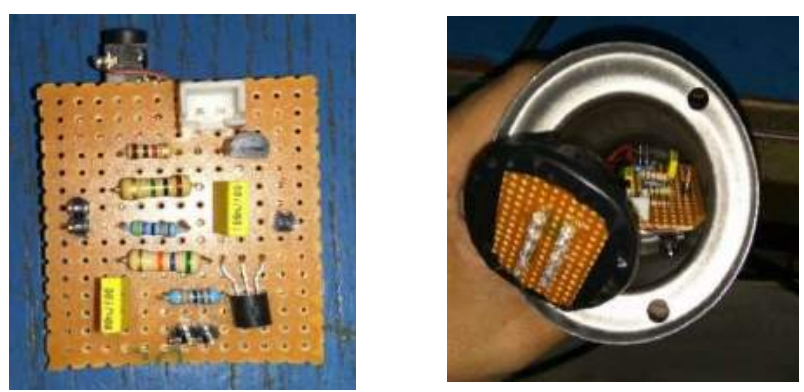

Gambar 5. Hasil Implementasi Sistem Receiver.

\section{HASIL DAN ANALISIS}

\subsection{Pengujian Sistem Tanpa Color filter dan Lensa}

Perancangan sistem ini meliputi blok pengirim (Tx) dan blok penerima (Rx) yang diletakkan di dalam akuarium berisi air. Blok diagram sistem VLC tanpa color filter dan lensa dapat dilihat pada Gambar 1. Pengujian ini antara kedua blok transmitter dan receiver yang dilakukan di dalam air dengan kedalaman $30 \mathrm{~cm}$. Perangkat lain yang digunakan adalah audio generator sebagai sumber informasi yang mengirimkan sinyal informasi dengan frekuensi $3 \mathrm{kHz}$, tegangan input $5 \mathrm{~V}$ dan oscilloscope yang berfungsi membandingkan antara informasi sinyal input dan informasi sinyal output yang berupa sinyal analog. Tabel 1 serta Gambar 6 menunjukkan hasil pengujian sistem dengan Vout yang semakin mengecil akibat semakin jauh jarak antara Tx dan Rx.

Tabel 1. Hasil Pengujian Sistem Tanpa Skenario

\begin{tabular}{|c|c|c|}
\hline Jarak (cm) & Vout (Vp-p) & Fout (kHz) \\
\hline 30 & 4.19 & 3.058 \\
50 & 3.40 & 2.992 \\
70 & 2.40 & 3.067 \\
90 & 1.20 & 3.145 \\
110 & 0.72 & 2.929 \\
130 & 0.72 & 3.125 \\
150 & 0.6 & 3.086 \\
\hline
\end{tabular}

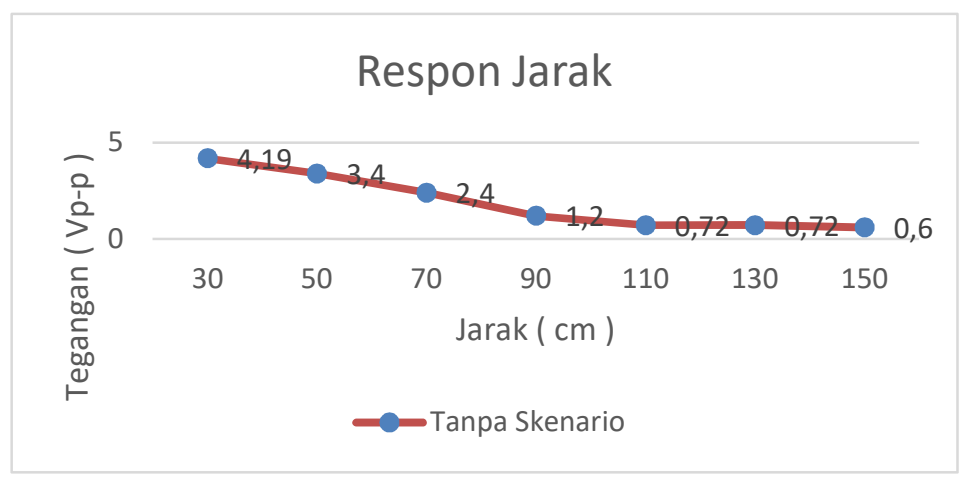

Gambar 6. Grafik Respon Jarak terhadap Tegangan pada Pengujian Tanpa Skenario 
Perbandingan bentuk sinyal yang dikirim pada pengirim (Tx) dengan sinyal yang diterima pada penerima (Rx) dari sistem tanpa skenario dengan jarak $90 \mathrm{~cm}$ dapat dilihat pada Gambar 7.

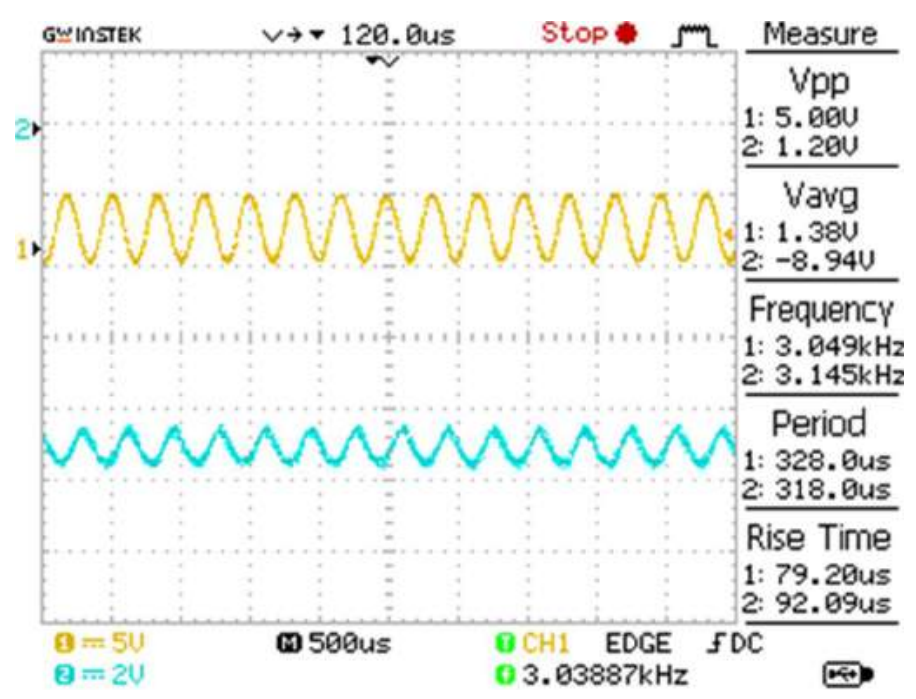

Gambar 7. Bentuk Sinyal untuk Pengujian Sistem Tanpa Skenario

\subsection{Pengujian Sistem dengan Color filter}

Perancangan sistem ini meliputi blok pengirim (Tx) dan blok penerima (Rx) yang diletakkan di dalam akuarium berisi air dengan memasangkan color filter setelah LED. Blok diagram sistem VLC dengan color filter dapat dilihat pada Gambar 8.

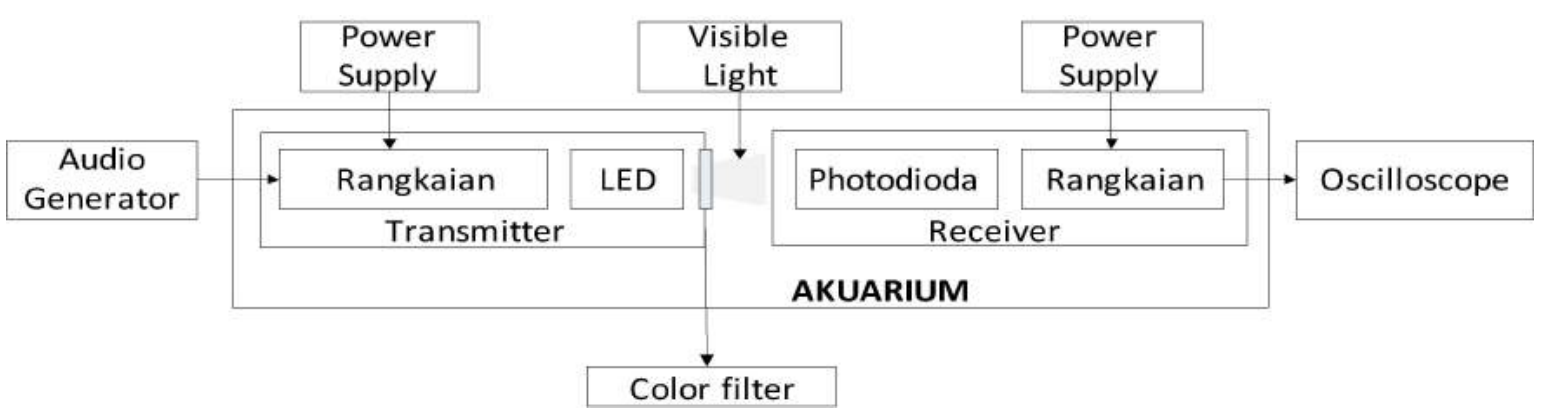

Gambar 8. Blok Diagram Sistem Visible Light Communication dengan Color filter.

Pengujian ini dilakukan untuk mengetahui perbandingan dengan kinerja sistem yang sebelumnya yaitu sistem tanpa skenario. Dari pengujian yang ditunjukkan di Tabel 2 dapat dilihat bahwa dari 6 color filter, hanya satu color filter, yaitu color filter dengan warna kuning (yellow) yang masih dapat terukur sampai jarak $150 \mathrm{~cm}$. Dari Tabel 2 terdapat nilai-nilai yang tidak terukur (NA). 
Tabel 2. Hasil Pengujian Sistem dengan Color filter

\begin{tabular}{|c|c|c|c|c|c|c|c|c|}
\hline \multirow{2}{*}{$\underset{(\mathrm{cm})}{\mathrm{d}}$} & \multicolumn{2}{|c|}{ Red } & \multicolumn{2}{|c|}{ Green } & \multicolumn{2}{|c|}{ Blue } & \multicolumn{2}{|c|}{ Cyan } \\
\hline & $\begin{array}{c}\text { Vout } \\
\text { (Vp-p) }\end{array}$ & $\begin{array}{c}\text { Fout } \\
\text { (kHz) }\end{array}$ & $\begin{array}{c}\text { Vout } \\
\text { (Vp-p) }\end{array}$ & $\begin{array}{c}\text { Fout } \\
\text { (kHz) }\end{array}$ & $\begin{array}{c}\text { Vout } \\
\text { (Vp-p) }\end{array}$ & $\begin{array}{c}\text { Fout } \\
\text { (kHz) }\end{array}$ & $\begin{array}{l}\text { Vout } \\
\text { (Vp-p) }\end{array}$ & $\begin{array}{c}\text { Fout } \\
\text { (kHz) }\end{array}$ \\
\hline 30 & 3.4 & 3.101 & 2.79 & 3.067 & 3.11 & 3.049 & 3.83 & 3.030 \\
\hline 50 & 1.2 & 3.030 & 1 & 2.967 & 1.24 & 3.067 & 1.75 & 2.982 \\
\hline 70 & 0.64 & NA & 0.6 & 3.148 & 0.68 & 3.010 & 0.88 & 3.186 \\
\hline 90 & 0.52 & NA & 0.52 & NA & 0.64 & NA & 0.6 & 3.125 \\
\hline 110 & 0.48 & NA & 0.48 & NA & 0.52 & NA & 0.52 & NA \\
\hline 130 & 0.48 & NA & 0.48 & NA & 0.48 & NA & 0.48 & NA \\
\hline 150 & 0.48 & NA & 0.48 & NA & 0.48 & NA & 0.48 & NA \\
\hline \multirow{2}{*}{$\underset{(\mathrm{cm})}{d}$} & \multicolumn{2}{|c|}{ Magenta } & \multicolumn{2}{|c|}{ Yellow } & & & & \\
\hline & $\begin{array}{l}\text { Vout } \\
\text { (Vp-p) }\end{array}$ & $\begin{array}{l}\text { Fout } \\
\text { (kHz) }\end{array}$ & $\begin{array}{c}\text { Vout } \\
\text { (Vp-p) }\end{array}$ & $\begin{array}{c}\text { Fout } \\
(\mathrm{kHz})\end{array}$ & & & & \\
\hline 30 & 0.64 & 2.901 & 4.4 & 3.003 & & & & \\
\hline 50 & 0.6 & NA & 3 & 3.044 & & & & \\
\hline 70 & 0.52 & NA & 1.67 & 3.012 & & & & \\
\hline 90 & 0.48 & NA & 1 & 3.063 & & & & \\
\hline 110 & 0.56 & NA & 0.76 & 3.080 & & & & \\
\hline 130 & 0.56 & NA & 0.68 & 2.959 & & & & \\
\hline 150 & 0.56 & NA & 0.48 & 2.925 & & & & \\
\hline
\end{tabular}

Perbandingan nilai tegangan terhadap jarak antara semua color filter dapat dilihat pada Gambar 9.

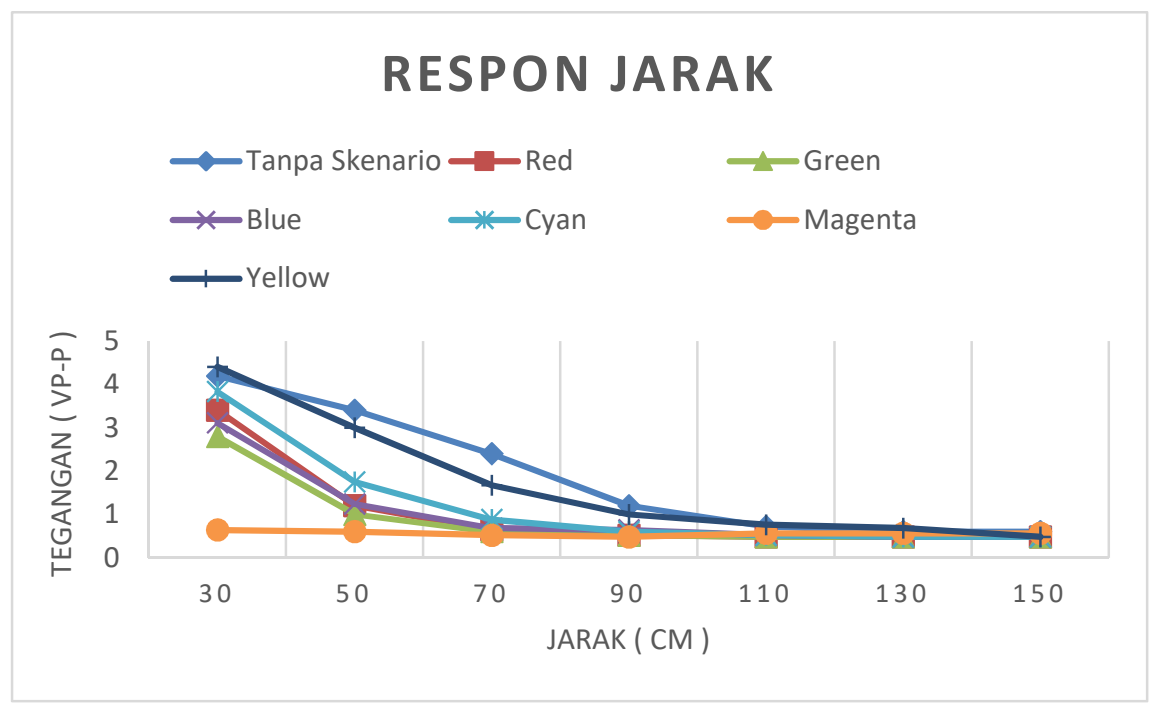

\section{Gambar 9. Grafik Respon Jarak terhadap Tegangan pada Pengujian Sistem dengan Color Filter}

Perbandingan bentuk sinyal informasi yang dikirim pada pengirim $(T x)$ dengan sinyal keluaran yang diterima pada penerima $(\mathrm{Rx})$ dari sistem dengan color filter yellow dan magenta yang berjarak $90 \mathrm{~cm}$ dapat dilihat pada Gambar 10 dan Gambar 11. 


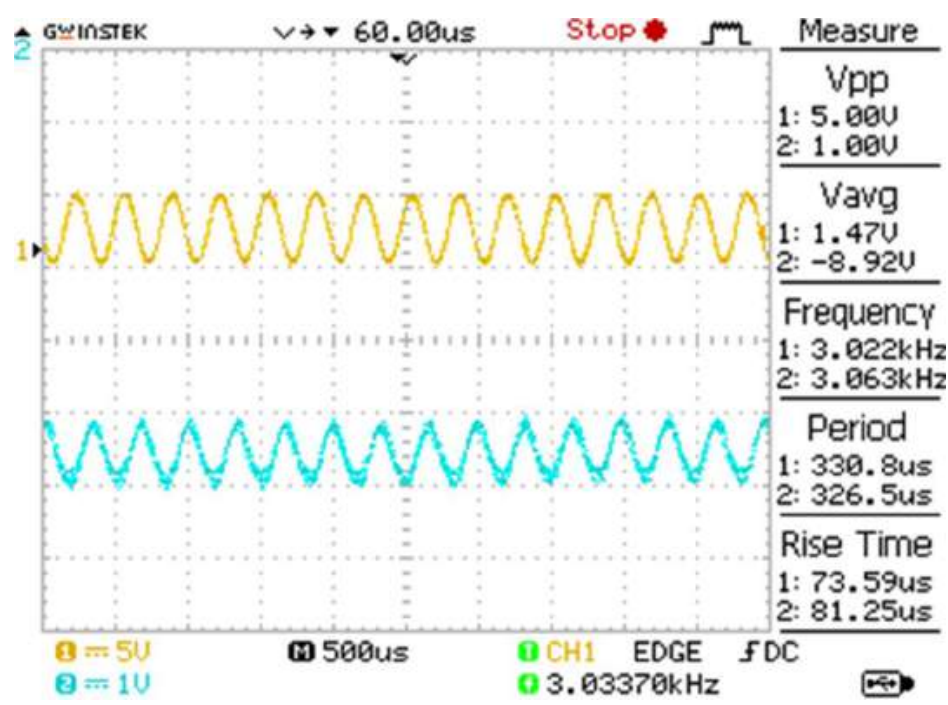

Gambar 10. Bentuk Sinyal pada Sistem dengan Color Filter Yellow $(90 \mathrm{~cm})$

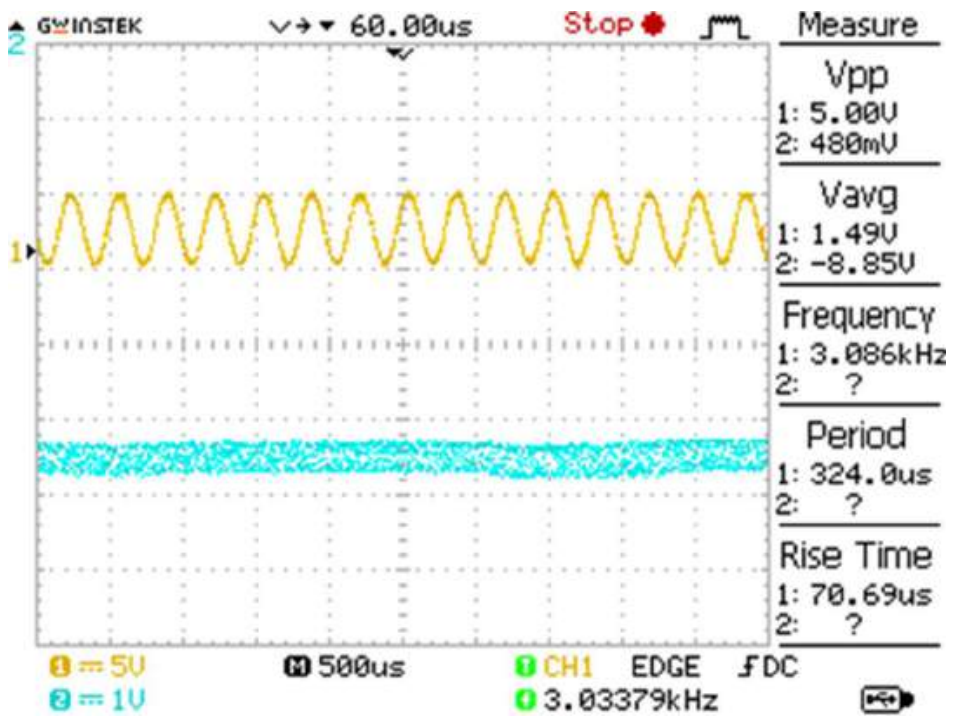

Gambar 11. Bentuk Sinyal pada Sistem dengan Color filter Magenta $(90 \mathrm{~cm})$

\subsection{Pengujian Sistem dengan Lensa}

Perancangan sistem ini meliputi blok pengirim (Tx) dan blok penerima (Rx) yang diletakkan di dalam akuarium berisi air. Blok diagram sistem VLC dengan lensa seperti pada Gambar 12.

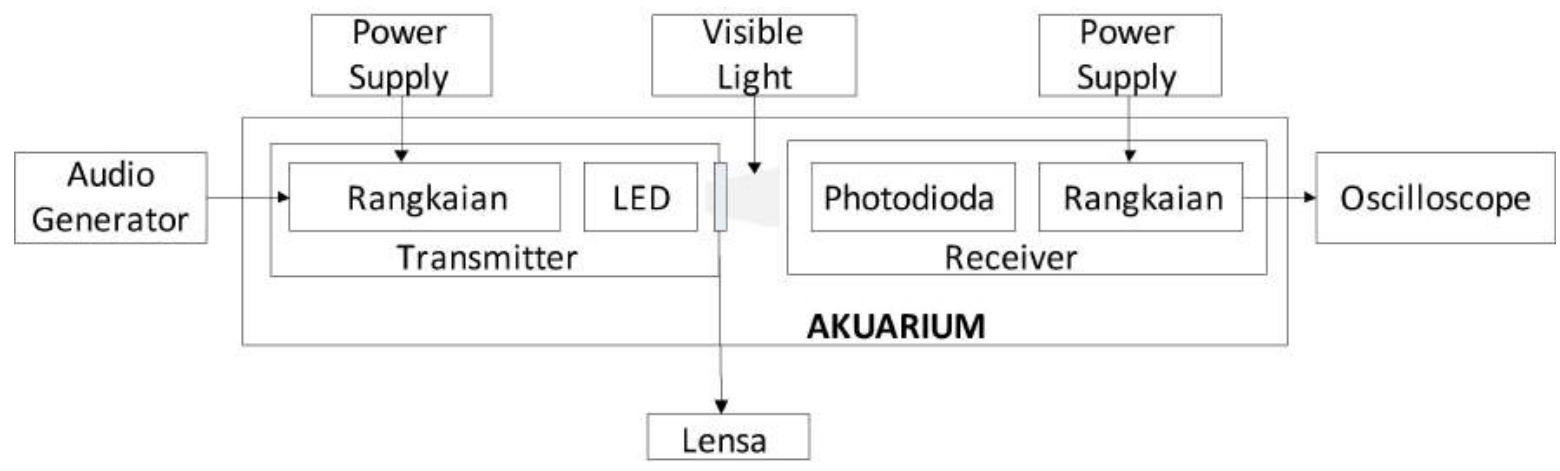

Gambar 12. Blok Diagram Sistem Visible Light Communication dengan Lensa. 
Tabel hasil pengujian system VLC dengan lensa dapat dilihat pada Tabel 3 berikut :

Tabel 3. Hasil Pengujian Sistem Dengan Lensa

\begin{tabular}{|c|c|c|c|c|c|c|c|c|}
\hline \multirow{2}{*}{$\begin{array}{c}D \\
(\mathrm{~cm})\end{array}$} & \multicolumn{2}{|c|}{$(+50)$} & \multicolumn{2}{|c|}{$(+100)$} & \multicolumn{2}{|c|}{$(+200)$} & \multicolumn{2}{|c|}{$(+300)$} \\
\hline & $\begin{array}{c}\text { Vout } \\
\text { (Vp-p) }\end{array}$ & $\begin{array}{c}\text { Fout } \\
\text { (kHz) }\end{array}$ & $\begin{array}{c}\text { Vout } \\
\text { (Vp-p) }\end{array}$ & $\begin{array}{l}\text { Fout } \\
\text { (kHz) }\end{array}$ & $\begin{array}{c}\text { Vout } \\
\text { (Vp-p) }\end{array}$ & $\begin{array}{l}\text { Fout } \\
\text { (kHz) }\end{array}$ & $\begin{array}{c}\text { Vout } \\
\text { (Vp-p) }\end{array}$ & $\begin{array}{c}\text { Fout } \\
\text { (kHz) }\end{array}$ \\
\hline 30 & 4.4 & 3.051 & 4.4 & 3.012 & 4.4 & 3.041 & 4.4 & 3.049 \\
\hline 50 & 3.79 & 2.970 & 3.59 & 3.067 & 3.4 & 3.033 & 3.4 & 3.080 \\
\hline 70 & 2.31 & 3.049 & 2.24 & 3.069 & 2.16 & 3.012 & 2.07 & 2.986 \\
\hline 90 & 1.36 & 3.049 & 1.44 & 3.197 & 1.44 & 3.012 & 1.27 & 3.016 \\
\hline 110 & 1.08 & 3.130 & 1.03 & 3.030 & 1 & 3.072 & 1 & 3.107 \\
\hline 130 & 0.76 & 2.995 & 0.72 & 3.125 & 0.72 & 2.902 & 0.72 & 2.924 \\
\hline 150 & 0.6 & 3.012 & 0.6 & 3.045 & 0.68 & 3.311 & 0.64 & 3.203 \\
\hline \multirow{2}{*}{$\begin{array}{c}D \\
(\mathrm{~cm})\end{array}$} & \multicolumn{2}{|c|}{$(-100)$} & \multicolumn{2}{|c|}{$(-300)$} & & & & \\
\hline & $\begin{array}{l}\text { Vout } \\
\text { (Vp- } \\
\text { p)) }\end{array}$ & $\begin{array}{l}\text { Fout } \\
\text { (kHz) }\end{array}$ & $\begin{array}{c}\text { Vout } \\
\text { (Vp-p) }\end{array}$ & $\begin{array}{l}\text { Fout } \\
\text { (kHz) }\end{array}$ & & & & \\
\hline 30 & 4.4 & 3.032 & 4 & 3.049 & & & & \\
\hline 50 & 3.4 & 3.027 & 3.4 & 3.080 & & & & \\
\hline 70 & 1.91 & 3.007 & 1.84 & 3.088 & & & & \\
\hline 90 & 1.27 & 2.976 & 1.27 & 3.175 & & & & \\
\hline 110 & 0.8 & 3.083 & 0.84 & 3.089 & & & & \\
\hline 130 & 0.6 & 3.012 & 0.68 & 3.055 & & & & \\
\hline 150 & 0.54 & 3.030 & 0.52 & 2.941 & & & & \\
\hline
\end{tabular}

Pada Tabel 3 rata-rata peningkatan tegangan terjadi sekitar 0.21 volt dibandingkan dengan pengujian sistem tanpa skenario. Dari seluruh lensa yang digunakan ada satu lensa yang sedikit unggul dari pada lensa yang lainnya yaitu lensa dengan ukuran (+50), karena lensa $(+50)$ adalah lensa dengan ukuran paling cembung dan sejajar dengan sumbu utama. Lensa cembung memiliki karakteristik sinar yang sejajar dengan sumbu utama akan dibiaskan menuju titik fokus, untuk penjelasan dapat dilihat pada Gambar 13 dibawah ini.

Pengujian ini menggunakan lensa cekung serta cembung serta diperoleh hasil yang lebih baik dibandingkan menggunakan color filter, dimana semua jenis lensa dapat menerima informasi yang dikirimkan transmitter dan diterima receiver.

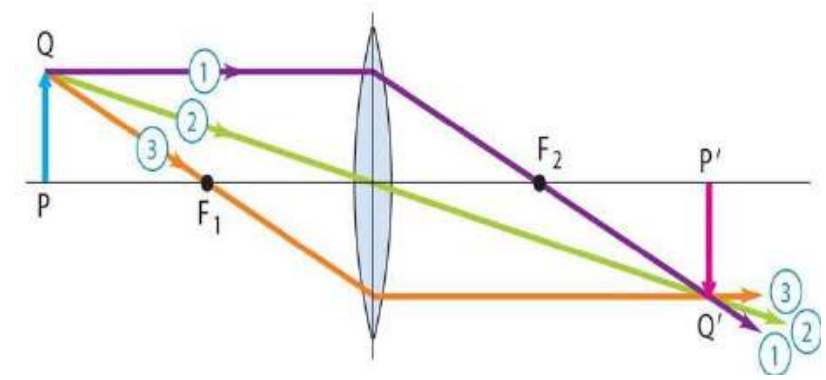

Gambar 13. Karakteristik Lensa Cembung (+)

Sinar istimewa 1: sinar yang sejajar sumbu utama lensa akan dibiaskan menuju titik fokus $\left(f_{2}\right)$ lensa.

Sinar istimewa 2: sinar yang menuju pusat lensa akan diteruskan

Sinar Istimewa 3: (kebalikan dari sinar istimewa 1) sinar yang melewati titik fokus lensa $\left(f_{1}\right)$ akan dibiaskan sejajar sumbu utama 
Grafik respon jarak terhadap tegangan untuk setiap lensa yang digunakan dapat dillihat pada Gambar 14.

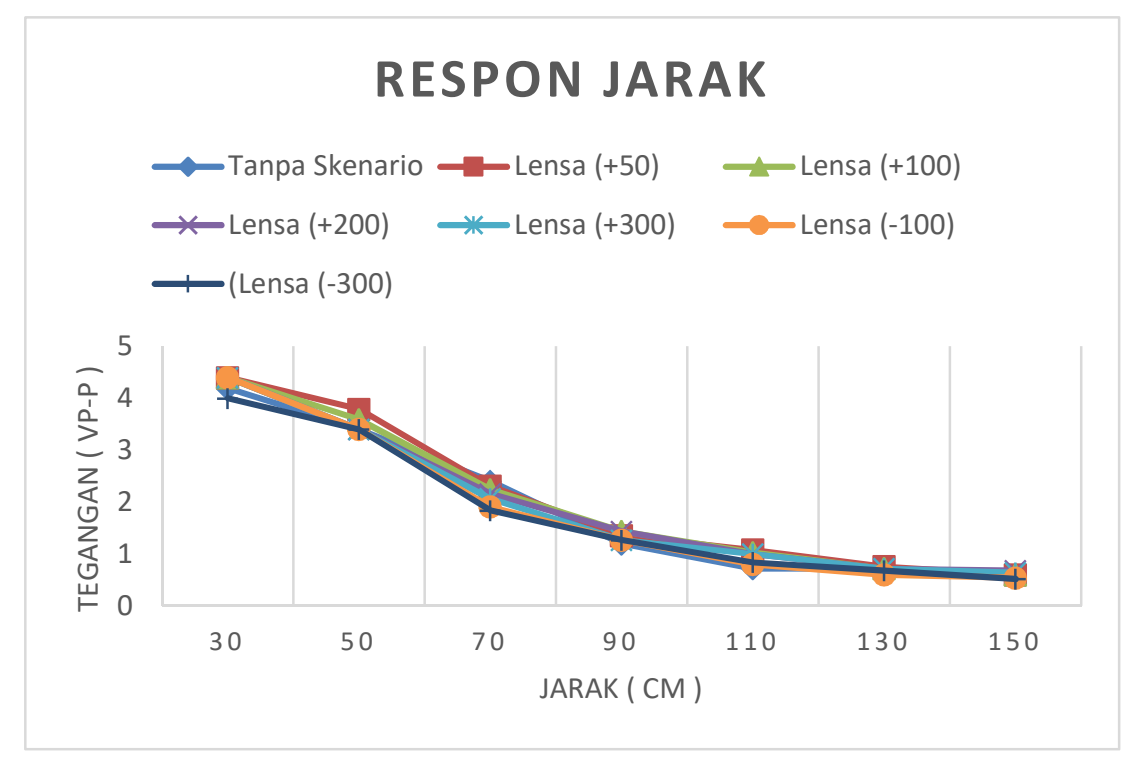

\section{Gambar 14. Grafik Respon Jarak Terhadap Tegangan pada Pengujian Sistem dengan Lensa.}

Perbandingan bentuk sinyal informasi yang dikirim pada pengirim $(T x)$ dengan sinyal keluaran yang diterima pada penerima dari pengujian sistem dengan lensa ukuran $(+50)$ dan $(-300)$ berjarak $90 \mathrm{~cm}$. Bentuk sinyal dapat dilihat pada Gambar 15 dan Gambar 16.

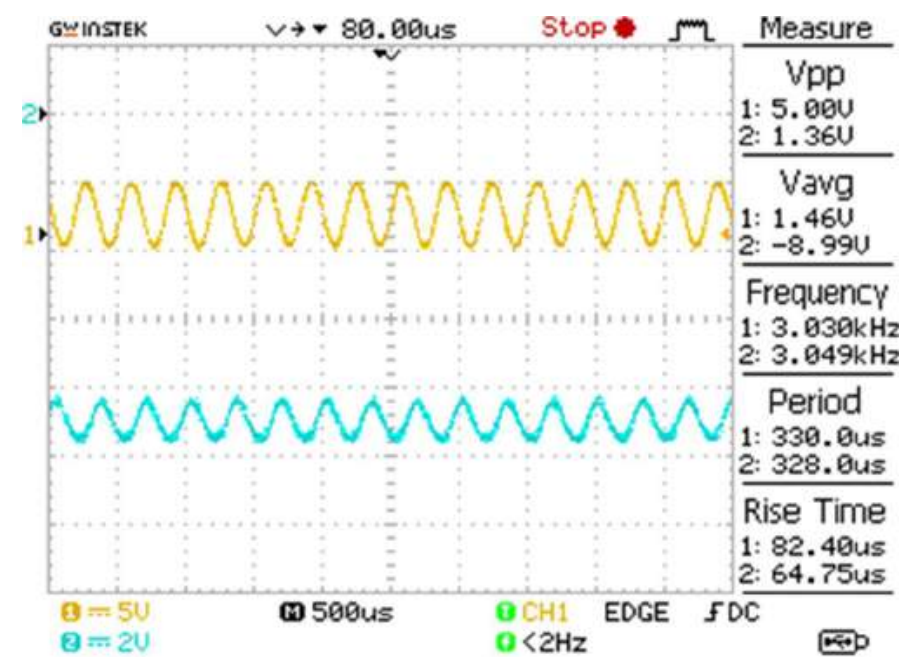

Gambar 15. Bentuk Sinyal pada Sistem dengan Lensa (+50). 


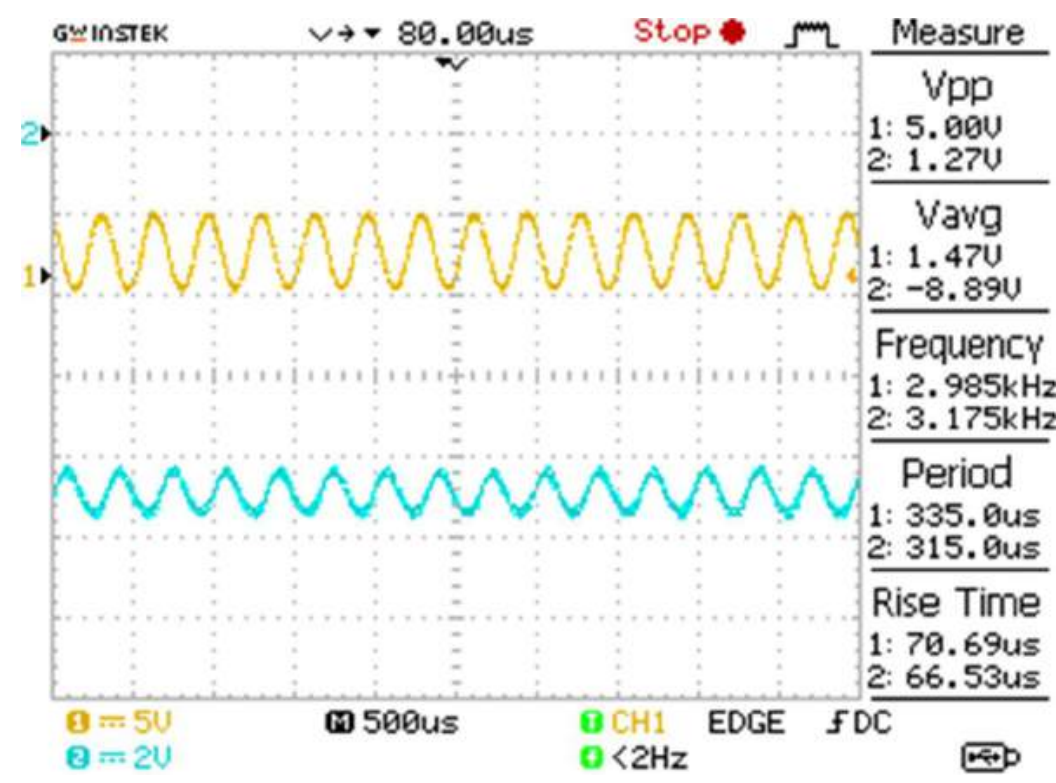

Gambar 16. Bentuk Sinyal pada Sistem dengan Lensa (-300)

\subsection{Pengujian Sistem dengan Lampu UV}

Perancangan sistem ini meliputi blok pengirim $(\mathrm{Tx})$ dan blok penerima $(\mathrm{Rx})$ yang diletakkan di dalam akuarium berisi air laut. Blok diagram sistem VLC dengan lampu UV seperti pada Gambar 17.

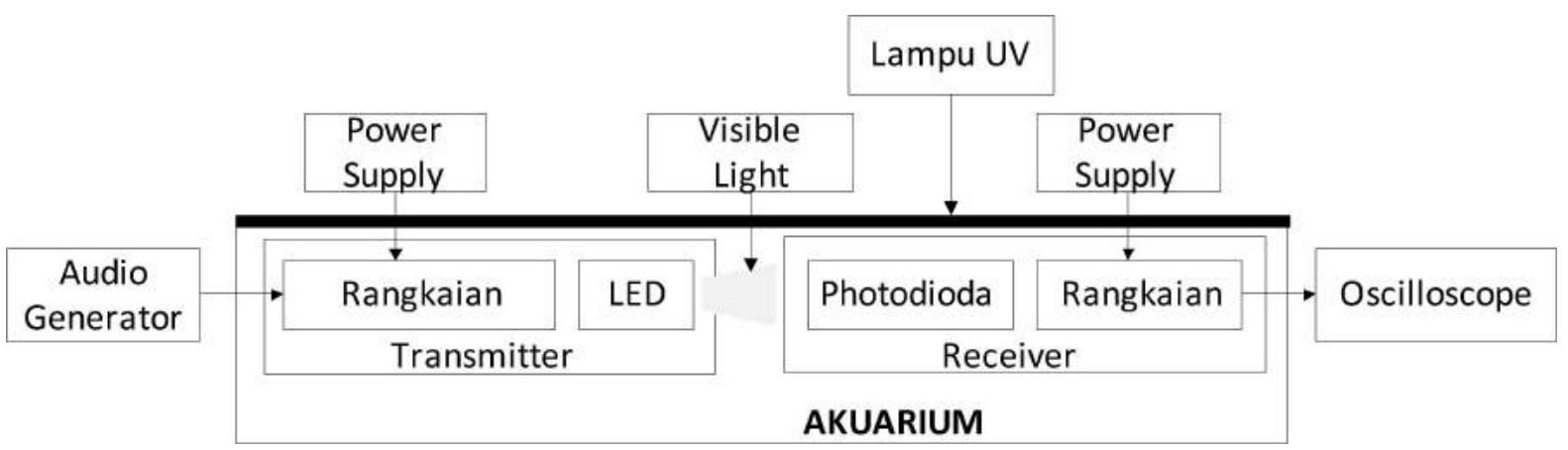

Gambar 17. Blok Diagram Sistem Visible Light Communication dengan Lampu UV

Pengujian ini menggunakan 3 lampu UV yang diletakkan di atas akuarium atau menutupi semua bagian pengiriman sinyal informasi dari transmitter menuju receiver.

Pada Tabel 4 dapat dilihat pengujian dengan lampu UV mengalami kenaikan rata-rata pada tegangan terjadi sekitar $0.21 \mathrm{Vp}$-p dibandingkan dengan pengujian sistem tanpa skenario akan tetapi berbanding terbalik dengan bentuk sinyal informasi yang diterima pada receiver. Itu disebabkan karena sinar UV bukan berada pada domain frekuensi cahaya tampak. Jadi kenaikan yang terjadi bukan menguatkan akan tetapi melemahkan kualitas frekuensi yang diterima. 
Tabel 4. Hasil Pengujian Sistem dengan Lampu UV

\begin{tabular}{|c|c|c|}
\hline Jarak (cm) & Vout (Vp-p) & Fout (kHz) \\
\hline 30 & 4.4 & 3.010 \\
50 & 4 & 3.067 \\
70 & 2.55 & 3.012 \\
90 & 1.36 & 3.096 \\
110 & 1.2 & 3.056 \\
130 & 0.8 & 3.045 \\
150 & 0.68 & 3.067 \\
\hline
\end{tabular}

Grafik respon jarak terhadap tegangan untuk pengujian dengan sistem UV dapat dilihat pada Gambar 18.

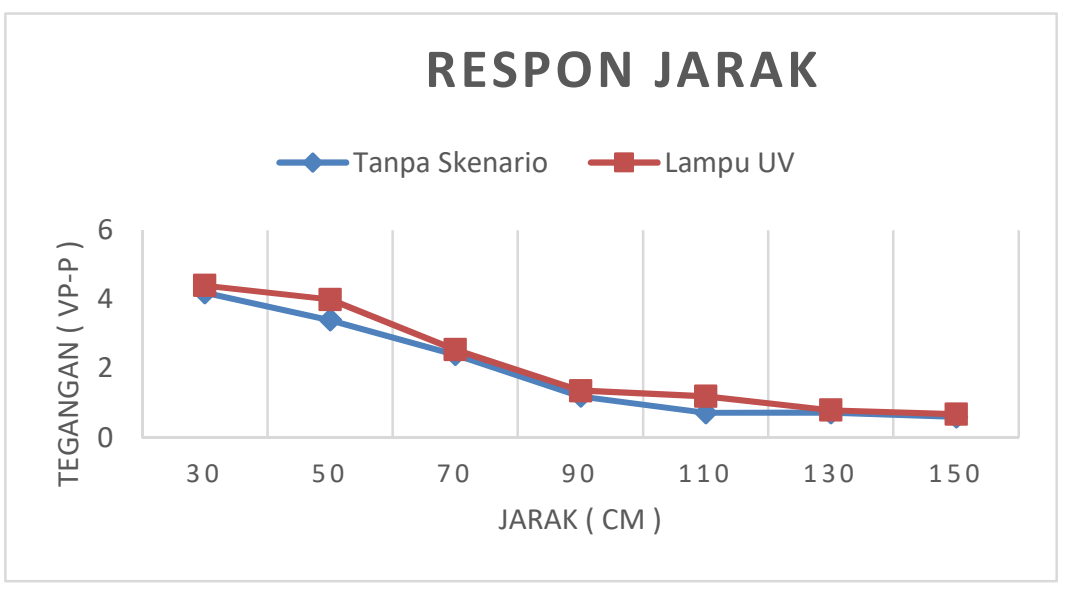

\section{Gambar 18. Grafik Respon Jarak Terhadap Tegangan pada Pengujian Sistem dengan Lampu UV.}

Perbandingan bentuk sinyal informasi yang dikirim pada Tx dengan sinyal keluaran pada Rx dari pengujian sistem dengan lampu UV berjarak $30 \mathrm{~cm}$ dan $90 \mathrm{~cm}$ dapat dilihat pada Gambar 19 dan Gambar 20.

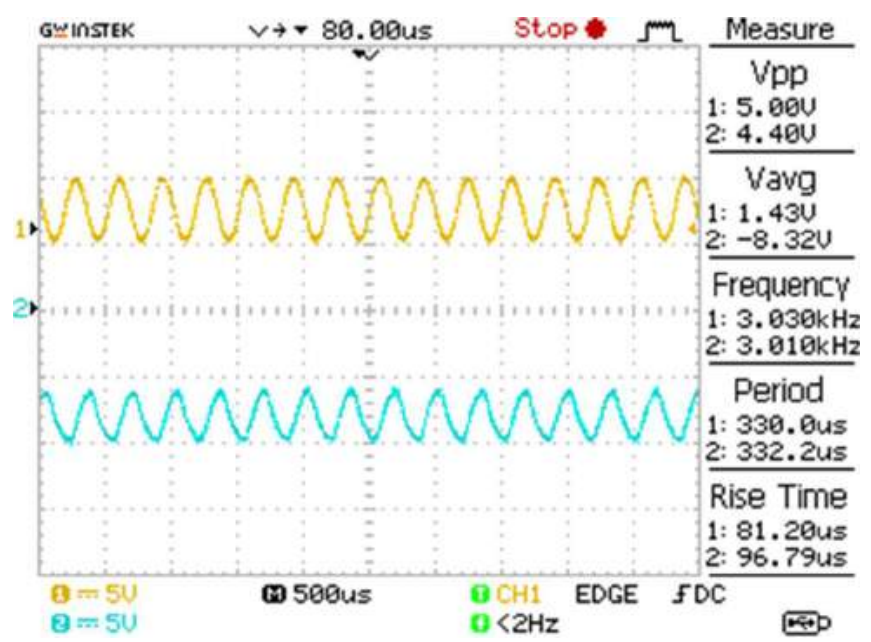

Gambar 19. Bentuk Sinyal pada Sistem dengan Lampu UV (30 cm) 
Sistem Komunikasi Suara Bawah Air dengan Metoda Simplex menggunakan Visible Light Communication (VLC)

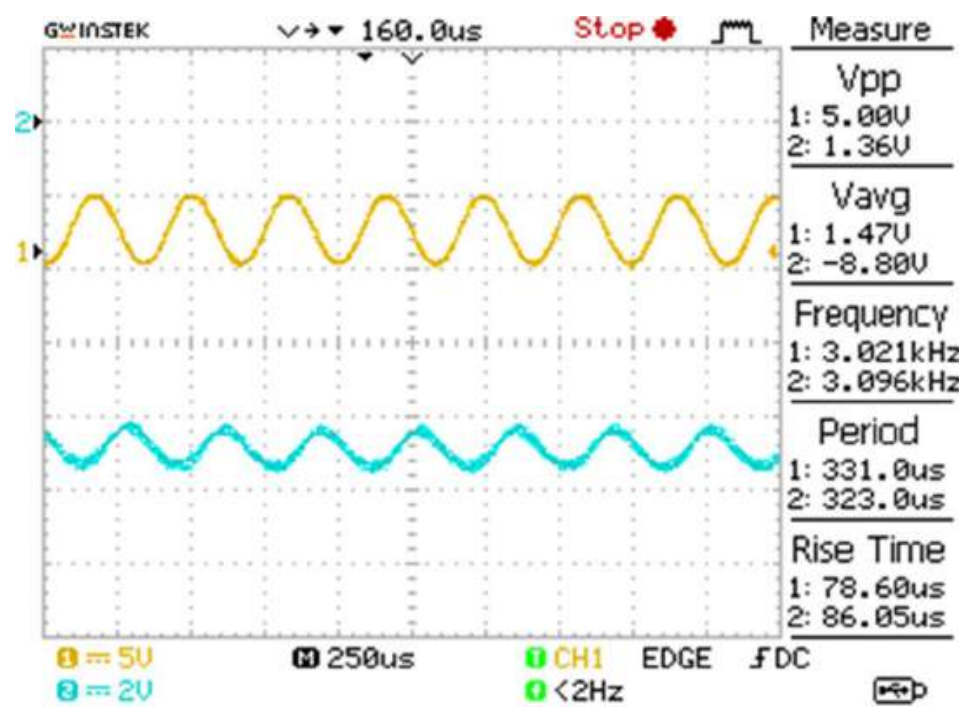

Gambar 20. Bentuk Sinyal pada Sistem dengan Lampu UV (90 cm)

Implementasi sistem VLC dengan menggunakan color filter red dan yellow dapat dilihat pada Gambar 21, Gambar 22 sedangkan Gambar 23 menunjukkan gambar keseluruhan sistem VLC dengan media air laut.

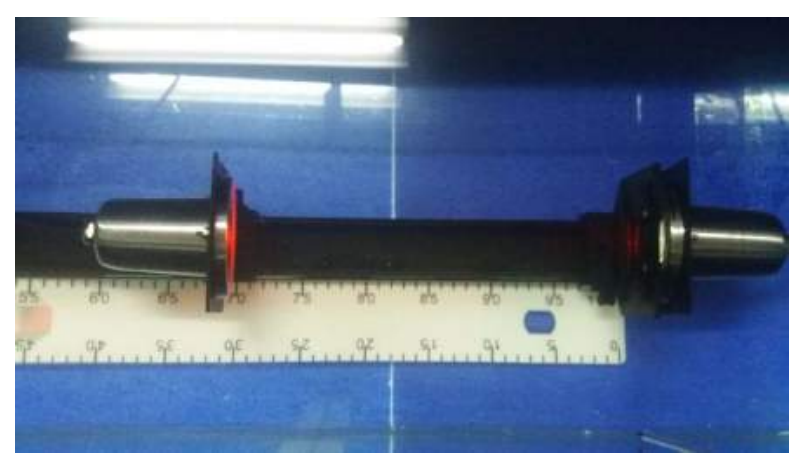

Gambar 21. Implementasi Sistem VLC menggunakan Color Filter Red

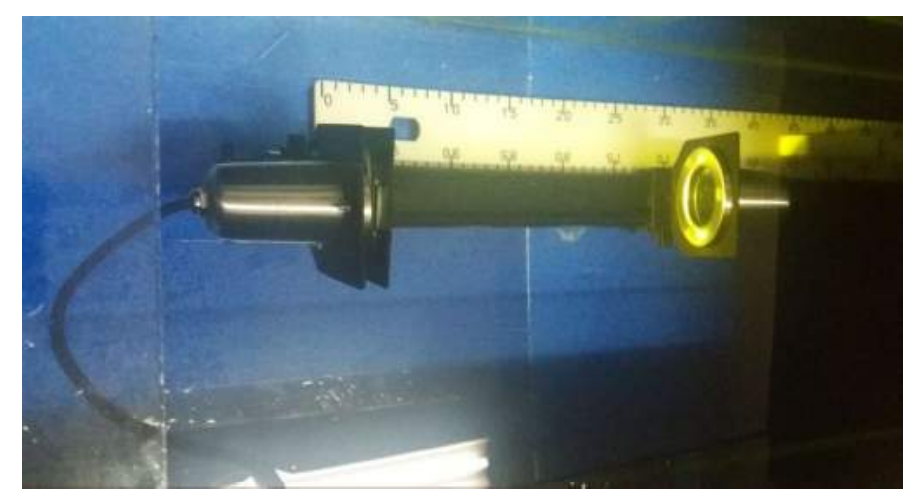

Gambar 22. Implementasi Sistem VLC menggunakan Color Filter Yellow 


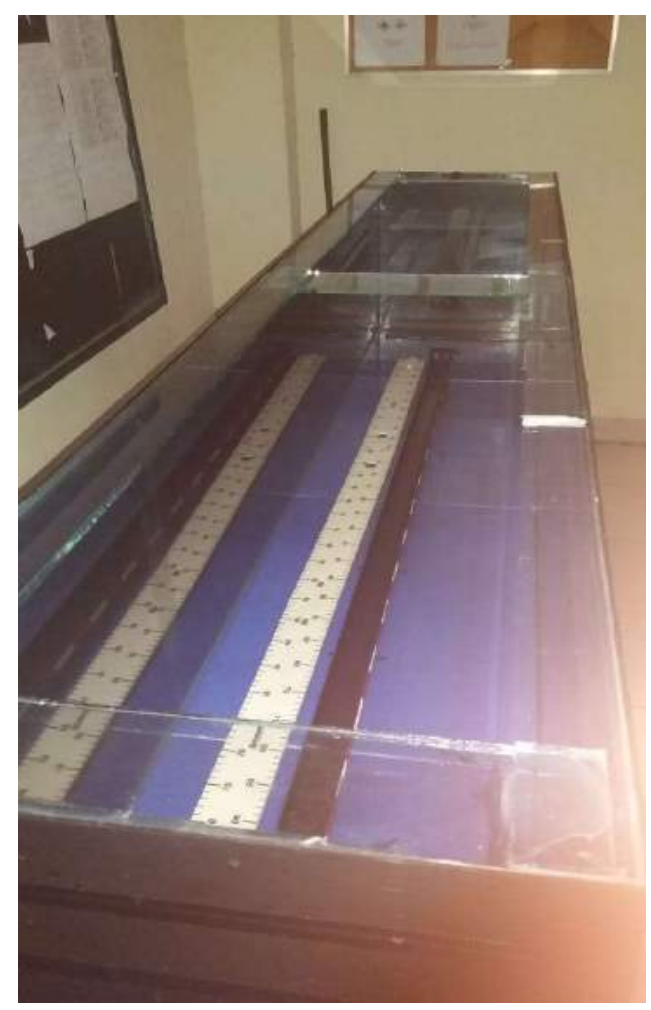

\section{Gambar 23. Implementasi Sistem VLC menggunakan Media Air Laut}

\section{KESIMPULAN}

Dari hasil perancangan, implementasi dan pengujian dapat diambil beberapa kesimpulan antara lain sebagai berikut :

1. Perangkat sistem $V L C$ yang dirancang dan diimplementasikan dapat menerima sinyal dengan frekuensi $3 \mathrm{kHz}$ di dalam air dengan jarak maksimal $150 \mathrm{~cm}$.

2. Pengujian sistem menggunakan color filter tidak disarankan kecuali warna kuning yang domain frekuensinya berada di daerah cahaya tampak dengan tegangan tertinggi 4,4 Vpp dan frekuensi $3,003 \mathrm{kHz}$.

3. Pengujian sistem menggunakan lensa dapat bekerja dengan baik yang dibuktikan untuk keseluruhan lensa dapat menerima sinyal informasi dengan tegangan tertinggi 4,4 Vp-p dan frekuensi 3,051 kHz untuk lensa (+50).

4. Pengujian sistem menggunakan lampu UV mengalami kenaikan tegangan mencapai 4,4 Vp-p dan frekuensi 3,010 kHz akan tetapi mengalami kerusakan pada bentuk sinyal yang diterima.

\section{DAFTAR RUJUKAN}

Alain Destrez, et al. (2012), Underwater High Bit Rate Optical Free Space Communication System. International Workshop on Optical Wireless Communication.

Darlis, Arsyad Ramadhan, et al. (2014). Implementasi Visible Light Communication (VLC) Pada Sistem Komunikasi. Elkomika, 1(1), 13 - 25. 
Darlis, A. R., et al. (2018). Bidirectional Underwater Visible Light Communication. International Journal of Electrical and Computer Engineering (IJECE), 8(6), 5203-5214.

Darlis, A. R., Lidyawati, L., \& Nataliana, D. (2016). Implementasi Visible LIght Communication (VLC) pada Sistem Komunikasi. Elkomika, 1(1), 13 - 25.

G. Cossu et al. (2012). Long Distance Indoor High Speed Visible Light Communication System Based on RGB LEDs. ACP Technical Digest (C) 2012 OSA

Sagotra, Aggarwal. (2013). Visible Light Communication (VLC). International Journal of Computer Trends and Technology, 4(4), 906 - 910. 